\title{
Ostracoda (Crustacea) from Lizard Island, northern Great Barrier Reef, Australia. II. The family Paradoxostomatidae Brady \& Norman, 1889
}

\author{
Patricia Behrens \\ Zoologisches Institut und Zoologisches Museum der Universität Hamburg; \\ Martin-Luther-King-Platz 3, D-W-2000 Hamburg 13, Federal Republic of Germany
}

\begin{abstract}
The present paper deals with the taxonomy of the ostracod family Paradoxostomatidae Brady \& Norman, 1889 from the coral reefs around Lizard Island, northern Great Barrier Reef, Australia. 18 species were found, all of them belonging to the genus Paradoxostoma Fischer, 1855. 2 species had been previously described from Heron Island, southern Great Barrier Reef. 1 species had been described from the Red Sea. 2 species are left in open nomenclature.
\end{abstract}

\section{INTRODUCTION}

This paper is the second on a series of investigations on the taxonomy, biology and ecology of benthic ostracods around Lizard Island, Great Barrier Reef. It deals with the taxonomy of the family Paradoxostomatidae. All species of this family that were found around Lizard Island belong to the genus Paradoxostoma Fischer, 1855. Of those scientists working in the Pacific, Hartmann $(1981,1984)$ was the only one, until recently, who collected living ostracods. Other collections have always consisted of dried sediment samples. As Paradoxostomatidae have very weakly calcified shells, few are preserved in dried sediment samples. This may be the reason why they have previously been recorded in such low abundances from the Pacific area. A large number of new species are described in this investigation, which is based on collections of living ostracods picked out of the substrate individually. Most species of the genus Paradoxostoma are highly adapted plant-suckers, predominantly occurring on macroalgae. Although coral reefs do not have a high abundance of large fleshy algae, there is a large amount of dead coral fragments covered with filamentous algae. This also seems to represent a favourable environment for species of Paradoxostoma, since the number of species found is large and 13 species were often found on dead coral fragments covered with filamentous algae.

For sampling stations, literature, materials and methods, refer to the paper "Ostracoda from Lizard Island, northern Great Barrier Reef, Australia. I." (Behrens, 1991: this volume). Holotypes and some paratypic material are deposited at the Australian Museum, Sydney. Paratypes are also deposited at the Zoologisches Museum, Hamburg. The aboriginal species names were taken from Reed (1965). 
Abbreviations: AMS = Australian Museum Sydney; $\mathrm{ZMH}=$ Zoologisches Museum Hamburg. LV = left valve; $R V=$ right valve; $A a=$ antennula; $A a=$ antenna; $M d=$ mandible; $M x u=$ maxillula; $P 1=$ first walking leg (maxilla); P2 = second walking leg; P3 = third walking leg.

\section{SYSTEMATIC DESCRIPTIONS}

\section{Genus Paradoxostoma Fischer, 1855}

In the genus Paradoxostoma, the main features for classification of species are the shape of the carapace, the proportions of the segments of the antennula, the bristles and claws of the antenna, the endites of the maxillula, the bristles of the walking legs, and the copulatory organ of the male. The bristles of the antennula are difficult to recognize and were not used in the taxonomic evaluation. They are, therefore, not illustrated.

\section{Paradoxostoma fuscumaculosum Hartmann, 1981}

Paradoxostoma fuscumaculosum Hartmann, 1981: 126-127, Figs 72-75.

Materia 1: 5 females, 4 males, August 16, 1989, Lizard Island, Sta. 12; AMS, ZMH $\mathrm{K}-\mathbf{3 4 5 5 5}$.

\section{Paradoxostoma heronislandensis Hartmann, 1981}

Paradoxostoma heronislandensis Hartmann, 1981: 127, Figs 76-79.

Materia l: Lizard Island: 1 male, May 18, 1988, Sta. 10; 1 female, May 18, 1988 , Sta. 11; 1 female, 1 male, August 16, 1989, Sta. 11; 4 females, 3 larvae, April 27, 1988, Sta. 12; AMS. 2 females, 3 larvae, April 27, 1988, Sta. 13; 1 male, August 8, 1989, Sta. 13; 1 female, May 16, 1988, Sta. 20; 1 female, May 10, 1988, Sta. 21; 1 female, August 14, 1989, Sta. 21; ZMH K-34556. Cod Hole: 1 female, August 7, 1989, Sta. 34; ZMH K-34556.

Paradoxostoma cf, navicula Bonaduce, Masoli, Minichelli \& Pugliese, 1980

(Figs 1-4)

Paradoxostoma navicula Bonaduce, Masoli, Minichelli \& Pugliese, 1980: 174, Plate 9: Fig. 13, Plate 10: Fig. 13, Plate 13: Fig. 9.

Material: Lizard Island: 1 larva, August 8, 1989, Sta. 13; 2 females, 3 males, 1 larva, May 3, 1988, Sta. 14; AMS. 9 females, 4 males, 1 larva, August 5, 1989, Sta. 14; 1 female, August 12, 1989, Sta. 25; ZMH K-34557.

$\mathrm{Siz}$ e: females, LV: length $1.00 \mathrm{~mm}$, height $0.25 \mathrm{~mm}$; males, LV: length $0.84 \mathrm{~mm}$, height $0.25 \mathrm{~mm}$.

Description of the soft parts: The Au has 6 segments with weak bristles. The Aa has 5 segments. The ventrodistal bristle on 2 is very small. The segments 3 and 4 ventrodistally have one bristle each. The terminal segment bears one small bristle and one claw. The spinneret bristle has 3 segments and is not longer than the end of the terminal claw. The Md is developed as a stinging organ. The Mxu has long endites and the inner endite bears two bristles. Walking legs: The knees of the walking legs have complex apodemes. P1 has a long thin bristle on the anterior margin of segment 1 . The kneebristle is strong and as long as the following segment. The kneebristle of P2 is also 
very long, but only half the length of the next segment. P3 has a weak kneebristle and a weak bristle on segment 2 .

Rem arks: Bonaduce et al. (1980) described $P$. navicula from the Red Sea. They did not describe the soft parts of the species. Since species of the genus have quite similar carapaces and differ mostly in their soft parts, certain classification is not possible. However, the present species has a very distinct and rare shape of the carapace, and the length of the male corresponds with the data given by Bonaduce et al. (1980).

\section{Paradoxostoma lizardensis sp. n.}

(Figs 5-7)

\section{Material}

Hol ot y pe: male, August 17, 1989, Lizard Island, Sta. 29; AMS.

Par aty pes: Lizard Island: 5 females, 2 males, March 15, 1988, Sta. 5; AMS. 1 female, May 18, 1988, Sta. 11; 1 female, August 12, 1989, Sta. 25; 5 females, 1 male, August 17, 1989, Sta. 29; ZMH K-34558.

L ocus typicus: Lizard Island, dead coral fragments.

$\mathrm{N}$ a m e: The species name refers to Lizard Island, the only place where P. lizardensis has been found.

Description: The dorsal margin is convex with its maximum height behind the middle of the carapace. In the anterior section it proceeds to a rounded anterior margin. The ventral margin is slightly concave in the region of the mouth. It meets with the dorsal margin in a caudal process. There is a large vestibule developed in the anterior part. In the region of the mouth, the inner margin and the line of concrescence nearly coincide. In the posterior part, the vestibule is narrower. There are about 15 marginal pore canals developed.

The $\mathrm{Au}$ has 6 segments with very weak bristles. The Aa has 5 segments with ventrodorsally one bristle on each of the segments 2,3 and 4 . There is only one terminal claw developed. The spinneret bristle has 3 segments and does not reach the end of the terminal claw. The Md is developed as a stinging organ. The Mxu has very long endites. All walking legs are slender and long. The apodemes of the knees are complex. P1 bears a thin bristle on the anterior margin of segment 1 . The kneebristle is strong, but not as long as the following segment. Segment 2 has one bristle at its anterior margin. The terminal claw is long. P2 has a very thin bristle at the anterior margin of 1 . The kneebristle is strong but short. The bristle on segment 2 has more than half the length of the following segment. P3 has a small kneebristle. The bristle on the anterior margin is about half the length of the following segment.

$\mathrm{Size}$ : females, LV: length $0.55 \mathrm{~mm}$, height $0.21 \mathrm{~mm}$; males, LV: length $0.58 \mathrm{~mm}$, height $0.22 \mathrm{~mm}$.

Remarks: Together with $P$. albaniensis Hartmann, 1979, $P$. exmouthensis Hartmann, 1978, $P$. devaneyi Hartmann, 1984, $P$. aculeatum and $P$. melania, $P$. lizardensis belongs to a group of elongated species with more or less developed caudal processes. It differs from the other species in the shape of the carapace and in the copulatory organ of the male. The length of the carapace in relation to its height is larger in P. Iizardensis and the anterior margin is more rounded. The copulatory organ of the male has two chitinous 
appendages like that of $P$. melania. However, the smaller of the two appendages of $P$. lizardensis forms an angle, whereas the one of $P$. melania is broader and not angular.

Paradoxostoma aculeatum sp. n.

(Figs 8-10, 43-44)

\section{Material}

Hol oty pe: male, May 16, 1988, Lizard Island, Sta. 2; AMS.

Par atypes: Lizard Island: 1 larva, May 18, 1988, Sta. 11; 1 female, 2 males, August 16, 1989, Sta. 11; 1 male, August 16, 1989, Sta. 12; 13 females, 6 males, 10 larvae, May 16, 1988, Sta. 20; AMS. 25 females, 16 males, 18 larvae, August 11, 1989, Sta. 20; 5 females, 5 males, 3 larvae, May 10, 1988, Sta. 21; 1 female, August 15, 1989, Sta. 23; 4 females, 1 male, August 17, 1989, Sta. 29; ZMH K-34559. Cod Hole: 4 females, 2 males, 1 larva, August 7, 1989, Sta. 34; ZMH K-34559. Hilder Reef: 1 female, 1 male, April 24, 1988, Sta. 36; ZMH K-34559.

L ocus typicus: Lizard Island, leeward side, dead coral fragments.

$\mathrm{Name:}$ The latin word "aculeatus" refers to the spur on the ventral margin of the carapace.

Description: The male carapace is similar in shape to that of the female carapace except that that of the male is slightly higher. Maximum carapace height is at the middle of the dorsal margin. The anterior margin is rounded. The ventral margin runs in a straight line to the posterior margin. There is a selvage which forms a distinct spur at the posterior end of the ventral margin. In the anterior part of the carapace, a broad vestibule is developed. In the mouth area, the inner margin and the line of concrescence coincide. There is also a small vestibule in the posterior part of the carapace. 16 marginal pore canals are equally distributed.

The Au has 6 segments, is slender and has thin bristles that are difficult to recognize. The Aa has 5 segments, ventrodistally with one bristle on each segment 2,3 and 4 . One of the terminal claws is strong, the other is developed as a bristle. The spinneret bristle is longer than the end of the terminal claw. The Md is developed as a stinging organ. The edge of the Mxu bears a small hook. Walking legs: P1 has a weak bristle at the ventral margin, a very strong kneebristle which is more developed as a claw and a small bristle at the ventral margin of segment 2. P2 and P3 have weak kneebristles and small bristles at the ventral margins of segment 2 . The copulatory organ of the male is a simple structure, with two thin appendages,

Si z e : females, LV: length $0.67 \mathrm{~mm}$, height $0.26 \mathrm{~mm}$; males, LV: length $0.70 \mathrm{~mm}$, height $0.30 \mathrm{~mm}$.

Re m a rks : $P$. aculeatum differs from the other species in having a distinct spur on the ventral margin of the carapace. The other species of the group with elongated carapaces have two large, chitinous appendages at the copulatory organ of the male, but the copulatory organ of $P$. aculeatum is a simple structure. One of the two appendages is very small, almost lacking. 
Paradoxostoma melania sp. $\mathrm{n}$.

Material

(Figs 11-15)

Hol o ty pe: male, May 8, 1988, Lizard Island, Sta. 24; AMS.

Par aty pes: Lizard Island: 1 female, August 14, 1989, Sta. 5; 1 male, March 19, 1988, Sta. 6; 1 female, August 16, 1989, Sta. 11; 1 female, April 27, 1988, Sta. 13; 1 larva, August 8, 1989, Sta. 13; 4 females, 4 males, 1 larva, August 11, 1989, Sta. 20; AMS. 1 male, August 14, 1989, Sta. 21; 1 female, August 15, 1989, Sta. 23; 1 female, May 17, 1988, Sta. 25; 1 female, 1 larva, August 12, 1989, Sta. 25; ZMH K-34560. Hilder Reef: 1 female, 1 male, 1 larva, April 24, 1988, Sta. 36; ZMH K-34560.

L o cus typicus: Lizard Island, reef flat, bluegreen algae.

$\mathrm{N}$ a m e : The greek word "melania" means black spot and refers to the spots of the carapace.

Description: The outline of the carapace of males and females is similar except that the females' carapaces are higher. The dorsal margin is slightly convex. The anterior margin is slightly rounded. The ventral margin runs nearly straight, from the anterior end to the posterior margin where it forms a caudal process. The inner margin and the line of concrescence do not coincide. There is a large vestibule in the anterior section of the carapace. The species has approximately 15 marginal pore canals. A distinct selvage is present at the ventral margin. The shell is transparent but covered with small, black spots.

The Au has 6 segments with very weak bristles. The Aa has 5 segments and the spinneret bristle nearly reaches the end of the terminal point. Distoventrally there is one bristle on each of the segments 2, 3 and 4. One of the terminal claws is very strong, the other weak. The Md is developed as a stinging organ. The Mxu has very long endites. Walking legs: P1 has one small bristle at the anterior margin of segment 1 . The kneebristle is very strong and as long as the following segment. P2 bears a thin bristle on the anterior margin of 1 . The kneebristle is strong, but has only half the length of the following segment. The bristle on segment 2 is strong. The kneebristle of P3 is weak, also the bristle on segment 2 . The anterior margin of the terminal segment is covered with long hair.

S i z e : females, LV: length $0.89 \mathrm{~mm}$, height $0.35 \mathrm{~mm}$; males, LV: length $0.92 \mathrm{~mm}$, height $0.35 \mathrm{~mm}$.

Remarks: P. melania is the largest of the elongated species. It also differs in the colour of the carapace, which is covered with distinct small, black spots. The second appendage of the copulatory organ of the male is broad and larger than that of the other species. $P$. melania largely resembles $P$. devaneyi Hartmann, 1984. However, the Aa of $P$. melania has two terminal claws whereas the Aa of $P$. devaneyi only has one. Also the kneebristle of $\mathrm{P} 2$ of $P$. devaneyi is longer than the next segment, which is a very unusual character.

\section{Paradoxostoma moonga sp. $\mathrm{n}$.}

(Figs 16-19)

Material

Holoty pe: male, May 16, 1988, Lizard Island, Sta. 20; AMS. 
P a r a ty pes: Lizard Island: 4 females, 3 males, August 24, 1989, Sta. 4 ; 4 females, 1 male, 1 larva, August 23, 1989, Sta. 6; 4 females, 2 males, May 18, 1988, Sta. 11; 16 females, 11 males, 2 larvae, August 16, 1989, Sta. 11; 2 females, 1 male, 2 larvae, April 24, 1988, Sta. 13; 2 females, 3 males, August 8, 1989, Sta. 13; AMS. 2 females, 3 males, May 3 , 1988, Sta. 14; 4 females, 5 larvae, August 5, 1989, Sta. 14; 12 females, 9 males, 3 larvae, May 16, 1988, Sta. 20; 1 female, 1 male, August 11, 1989, Sta. 20; 1 female, 1 male, May 10, 1988, Sta. 21; 2 females, 1 larva, August 14, 1989, Sta. 21; 1 female, May 19, 1988, Sta. 23; 1 female, 2 males, 1 larva, August 15, 1989, Sta. 23; 2 females, August 17, 1989, Sta. 29; ZMH K-34561.

L ocus typicus : Lizard Island, dead coral fragments covered with algae.

Name: The aboriginal word "moonga" means dark.

Description: The dorsal margin of the carapace is convex with its maximum height in the mid shell region. In the anterior part, the dorsal margin extends almost to the ventral margin. There is no clearly developed anterior margin. The posterior end is slightly more rounded. The ventral margin is straight. The inner margin and the line of concrescence are separated. In the anterior region, the vestibule is more developed. The marginal pore canals are short, their number is about 16 . The shell shows a dark colouration along the dorsal margin or over the entire carapace.

The Au has 6 segments: the bristles are weak. The Aa has 5 segments. The spinneret bristle, which has a short second segment, reaches the end of the terminal claw. Distoventrally, the segments 2 and 4 each have one bristle, and segment 3 has two bristles. The terminal segment has only one claw and no bristle at its side. The Md is developed as a stinging organ. The Mxu is without special features. Walking legs: P1 has one bristle at the anterior margin of segment 1 . The posterior margin is covered by long hair. The kneebristle is strong and longer than the following segment. The bristle on segment 3 is small. P2 also has a bristle at the anterior margin of segment 1 . The kneebristle is strong but not as long and the bristle on segment 3 is well developed. P3 bears a thin hairy kneebristle. The bristle on segment 2 is smaller than that on P2. The terminal claw is long.

Si z e : females, LV: length $0.46 \mathrm{~mm}$, height $0.21 \mathrm{~mm}_{\text {; }}$ males, LV: length $0.47 \mathrm{~mm}$, height $0.22 \mathrm{~mm}$.

Re m a rks : $P$. moonga belongs to the arcuatum-group, which was established by Hartmann (1978) for a group of closely related species. $P$. moonga differs from $P$. pararcuata Hartmann, 1978 in the size of the carapace. $P$. pararcuata is larger than $P$. moonga. The P2 of $P$. pararcuata does not have a bristle on segment 1 like that in $P$. moonga, and the kneebristle is not strong. $P$. moonga differs from $P$. paenearcuatum Hartmann, 1978 with respect to the antenna, which, in $P$. moonga, does not have a small hook besides the terminal claw. The basal capsule of the copulatory organ of $P$. moonga is broader than that of $P$. paenearcuatum, and one of the appendages is shorter. $P$. propearcuatum Hartmann, 1978 differs in the shape of the carapace. The species has a small caudal process which is not developed in $P$. moonga. The copulatory organ of the male of $P$. propearcuatum differs in having two large appendages, the second one located ventrad. $P$. moonga can also be distinguished from the other species by its dark colour. The carapace shows a dark colouration along the dorsal margin or over the entire carapace. 
Paradoxostoma tiwiwarrin sp. n.

(Figs 20-23)

\section{Material}

Hol otype: male, May 18, 1988, Lizard Island, Sta. 10; AMS.

Paratypes: Lizard Island: 1 male, August 23, 1989, Sta. 6; 5 females, 1 male, April 27, 1988, Sta. 13; 1 female, August 8, 1989, Sta 13; AMS. Cod Hole: 5 females, 2 males, August 7, 1989, Sta, 34; ZMH K-34562.

Locus ty picus: Lizard Island, dead coral fragments covered with algae.

Name: The aboriginal word "tiwiwarrin" means fast.

Description: The anterior portion of the dorsal margin of the carapace is slightly convex and the anterior margin is rounded. The ventral margin runs in a straight line. There is no distinct demarcation between the ventral and the posterior margin, but the latter steeply declines from the dorsal margin. The inner margin and line of concrescence do not coincide except at a small point in the mouth region. There are about 15 marginal pore canals.

The Au has 6 segments, with weakly developed bristles. The Aa has 5 segments, with a 3-segmented spinneret bristle which is not longer than the end of the terminal claw. The second, third and fourth Aa segments each bear one bristle on their ventrodistal sides. The terminal claw is strong and has one small bristle at its side. The Md is developed as a stinging organ. The Mxu has long endites, the inner endite bears only one bristle. Walking legs: The bristle on the ventral margin of $P 1$ is quite small, but the kneebristle is relatively strong and extends to the following segment. Similarly, P2 has a short, thin ventral bristle and a strong kneebristle that is half the length of the following segment. The kneebristle and the ventral bristle on segment 2 of P3 are weak. Segment 3 bears bristle-like hairs.

$\mathrm{S}$ i z e : females, LV: length $0.68 \mathrm{~mm}$, height $0.29 \mathrm{~mm}$; males, LV: length $0.71 \mathrm{~mm}$, height $0.29 \mathrm{~mm}$.

Re m a r k : P. tiwiwarrin differs from all other species in the shape of its carapace. The posterior margin declines steeply from the dorsal margin to the anterior margin, and the dorsal margin runs almost in a straight line.

\section{Paradoxostoma virgatum sp. $\mathrm{n}$.}

(Figs 24-26)

Material

Hol otype: male, May 3, 1988, Lizard Island, Sta. 14; AMS.

Paratypes: Lizard Island: 13 females, 4 males, May 3, 1988, Sta. 14; AMS. 9 females, 4 males, 2 larvae, August 5, 1989, Sta. 14; 2 females, 1 male, 1 larva, August 14, 1989, Sta. 21; ZMH K-34563. Cod Hole: 3 females, 1 male, 1 larva, August 7, 1989, Sta. 34; ZMH K-34563.

L o cus ty picus: Lizard Island, reef flat, red algae.

$\mathrm{Name}$ : The latin word "virgatus" refers to the ornamentation of fine ridges.

Description: The dorsal margin reaches its maximum height behind the mid shell region. The posterior end is broadly rounded. Dorsal and ventral margins are convex. The anterior margin is less rounded than the posterior one. There is an ornamen- 
tation of very fine ridges running from the anterior to the posterior end. The inner margin and the line of concrescence never coincide. In the region of the mouth, the vestibule is narrower compared with the anterior and posterior regions, where the marginal pore canals are short. The number of pore canals is about 12 .

The Au has 6 segments with weak bristles. The Aa has 5 segments. The spinneret bristle reaches the end of the terminal claw. One terminal claw is developed having a small bristle at its side. The segments 2,3 and 4 distoventrally bear one small bristle each. The $\mathrm{Md}$ is developed as a stinging organ. The Mxu has long and slender endites. Walking legs: The apodemes of the walking legs are complex. P1 bears a thin bristle at the anterior margin of segment 1 . The kneebristle is strong and longer than the following segment. The bristle at the anterior margin of segment 2 is also strong and longer than the following segment, which is unusual. P2 has a strong kneebristle which is half the length of segment 3 . The kneebristle of $\mathrm{P} 3$ is thin, and the bristle on segment 2 strong.

$\mathrm{S}$ i z e : females, LV: length $0.65 \mathrm{~mm}$, height $0.28 \mathrm{~mm}$; males, LV: length $0.67 \mathrm{~mm}$, height $0.29 \mathrm{~mm}$.

Remarks: $P$, virgatum resembles $P$. congruens in the shape of the carapace. However, the posterior end of $P$. congruens is more rounded than that of $P$. virgatum. These two species differ in the size of their carapace. $P$. virgatum is distinctly larger than $P$. congruens. They can also be distinguished by the copulatory organ of the male. $P$. congruens has a small second appendage, which is not developed in $P$. virgatum.

\section{Paradoxostoma congruens sp. $\mathrm{n}$.}

(Figs 27-29)

\section{Material}

Hol otype: male, August 16, 1989, Lizard Island, Sta. 12; AMS.

Parat Y pes: Lizard Island: 1 female, May 14, 1988, Sta. 8; 1 female, August 16, 1989, Sta. 12; 2 females, 1 larva, May 17, 1988, Sta. 25; 1 female, 1 male, 1 larva, August 12, 1989, Sta. 25; AMS. Cod Hole: 2 females, 3 males, 1 larva, August 7, 1989, Sta. 34; ZMH K-34564.

L ocus typicus: Lizard Island, dead coral fragments covered with filamentous algae.

$\mathrm{N}$ a me: The latin word "congruens" refers to the uniform shape of the carapace.

Description: The dorsal margin is convex, reaching maximum height just posterior to the mid shell region. The ventral margin runs in almost a straight line. The posterior margin is broadly rounded, the anterior margin is narrower. The inner margin and the line of concrescence are well separated, and a large vestibule is developed. Therefore, the pore canals are short. They number about 15.

The Au has 6 segments with small bristles. The Aa has 5 segments. The spinneret bristle has 3 segments and it extends to the end of the terminal claw. The distoventral bristles on the segments 2, 3 and 4 are small. The terminal segment bears one claw and one small bristle. The $\mathrm{Md}$ is developed as a stinging organ. The first endite of the Mxu has only one bristle. Walking legs: P1 has a long, thin bristle at its anterior margin and a strong kneebristle that is longer than the following segment. The kneebristle on P2 is as long as the following segment but it is not as strong as the one on P1. The bristle on segment 2 is short. The kneebristle of P3 is very weak. Segment 2 bears a short bristle and 
segment 3 is covered with hair at the anterior margin, which gives the impression of a bristle.

Siz e: females, LV: length $0.49 \mathrm{~mm}$, height $0.21 \mathrm{~mm}$; males, LV: length $0.53 \mathrm{~mm}$, height $0.23 \mathrm{~mm}$.

Rem arks: see $P$. virgatum sp. n.

\section{Paradoxostoma waminoa sp. n.}

(Figs 30-32)

Material

Holotype: male, March 15, 1988, Lizard Island, Sta. 5; AMS.

Par a ty pes: Lizard Island: 1 female, March 15, 1988, Sta. $4 ; 3$ females, 2 males, March 15, 1988, Sta. 5; 4 females, 4 males, August 4, 1989, Sta. 5; 12 females, 8 males, 5 larvae, March 19, 1988, Sta. 6; 15 females, 10 males, 9 larvae, August 23, 1989, Sta. 6; AMS. 3 females, 1 male, May 14, 1988, Sta. 8; 3 females, April 27, 1988, Sta. 13; 17 females, 5 males, May 3, 1988, Sta. 14; 9 females, 4 males, 2 larvae, August 5, 1989, Sta. 14; 1 female, August 14, 1989, Sta. 21; ZMH K-34565.

L ocus ty picus: Lizard Island, reef flat, algae.

Name: The aboriginal word "waminoa" means companion and refers to the large population found.

Description: The dorsal margin of the carapace is extremely convex. Rounded tips are developed at the posterior and anterior ends at the same height. The ventral margin is slightly concave in the middle. The inner margin and the line of concrescence are well separated at the anterior and posterior parts of the shell. They nearly coincide in the region of the mouth. The number of marginal pore canals is about 15 .

The Au has 6 segments. The terminal segment is only half the length of the following one. The bristles are very small. The Aa has 5 segments, having a spinneret bristle longer than the terminal claw. The segments 2,3 , and 4 distoventrally have one bristle each. The terminal claw is strong, with a small bristle at its side. The Md is developed as a stinging organ. Walking legs: The anterior margin of $\mathrm{P} 1$ has a long but thin bristle. The kneebristle is extremely coarse and reaches the middle of segment 3 . The bristle on segment 3 is also coarse. The kneebristle of P2 is weaker. P3 bears a thin kneebristle. The top of the anterior margin of segment 3 is covered with hair, which gives the impression of a bristle.

$\mathrm{S}$ i z e : females, LV: length $0.51 \mathrm{~mm}$, height $0.22 \mathrm{~mm}$; males, LV: length $0.54 \mathrm{~mm}$, height $0.23 \mathrm{~mm}$.

Remarks: $P$. waminoa has an extremely convex dorsal margin with tips developed at the anterior and posterior ends and a concave ventral margin. This gives a unique shape to the carapace that differentiates $P$. waminoa from all other species. The copulatory organ of the male resembles that of $P$. congruens, but has a shorter copulatory tube which runs in a straight line whereas that of $P$. congruens runs in a circle. 
Paradoxostoma maldum sp. n.

(Figs 33-36)

Material

Hol o ty pe: male, August 4, 1989, Lizard Island, Sta. ?.

P a r a ty pe s: Lizard Island: 1 female, March 15, 1988, Sta. 5; AMS. 1 male, August 4, 1989, Sta. 5; 1 female, March 19, 1988, Sta. 6; ZMH K-34566.

Lo o u s ty picus : Lizard Island, reef flat, Halimeda sp.

Name: The aboriginal word "malde" means strange and refers to the unusual carapace shape.

Description: The dorsal margin of the carapace is convex with its maximum height in the mid region. The anterior margin is rounded. The ventral margin is nearly straight with a slightly concave part in the region of the mouth. The posterior margin has a rounded tip. It runs straight to the ventral margin. The inner margin and the line of concrescence never coincide. The vestibule is broad and therefore the marginal pore canals, about 13 , are short.

The Au has 6 segments. There are two long bristles on segment 4. The Aa is compact. Ventrodistally there is one long bristle on segment 2, and there are short bristles on segments 3 and 4 . The terminal segment bears one long claw and one bristle. The spinneret bristle is short, only reaching the base of the terminal claw. The Md is developed as a stinging organ and is extremely long. The Mxu has relatively short endites. Walking legs: P1 has a strong kneebristle which is as long as the following segment. The ventral bristle of segment 2 is weak. P2 and P3 have weak kneebristles and also weak bristles on segment 2 .

$\mathrm{S}$ i z e : females, LV: length $0.42 \mathrm{~mm}$, height $0.24 \mathrm{~mm}$; males, LV: length $0.43 \mathrm{~mm}$, height $0.24 \mathrm{~mm}$.

Re marks: The species that resembles $P$. maldum is $P$. geraldtonensis Hartmann, 1978. These species differ in the form of the anterior margin which is slightly concave in $P$. maldum but straight in $P$. geraldtonensis. The terminal claw of the antenna is much longer in $P$. maldum. The end of the appendage of the copulatory organ of the male is rounded in $P$. maldum but uneven in $P$. geraldtonensis.

\section{Paradoxostoma kurrawa sp. n.}

(Figs 37-38)

Material

Hol ot y p e: male, May 18, 1988, Lizard Island, Sta. 10; AMS.

P a r aty pes: Lizard Island: 2 females, 4 males, May 18, 1988, Sta. 10; AMS. 1 female, 1 male, May 18, 1988, Sta. 11; 1 female, April 27, 1988, Sta. 13; 2 females, August 17, 1989, Sta. 29; ZMH K-34567.

L o cus ty picus : Lizard Island, windward side, dead coral fragments.

$\mathrm{N}$ a me: The aboriginal word "kurrawa" means rough sea and refers to the locus typicus.

Description: The dorsal margin of the carapace is convex. The anterior margin is broadly rounded. The ventral margin has a small area in the region of the mouth where it is concave, but it is mostly convex. The posterior margin ends in a small caudal process. 
The inner margin and the line of concrescence never coincide. The vestibule is broad and the marginal pore canals are short. Their number is about 16 . The carapace of the female is higher than that of the male.

The Au has 6 segments with weak bristles. The Aa has 5 segments. Distoventrally the segments 2, 3 and 4 bear one bristle each. The spinneret bristle has 3 segments and does not reach the end of the terminal claw in length. The $\mathrm{Md}$ is developed as a stinging organ. The endites of the Mxu are relatively short. Walking legs: P1 has a small bristle at the anterior margin of segment 1 . The kneebristle is coarse and as long as the following segment. The bristle on segment 2 is short. P2 and P3 have a weak kneebristle each. The bristles on segment 2 are also short. The apodemes of the walking legs are complex structures.

Si z e : females; LV: length $0.55 \mathrm{~mm}$, height $0.30 \mathrm{~mm}$; males, LV: length $0.62 \mathrm{~mm}$, height $0.35 \mathrm{~mm}$.

Re marks: Like $P$. maldum, P. kurrawa resembles $P$. geraldtonensis Hartmann, 1978 in the shape of the carapace. However, $P$. kurrawa is larger than both species and has a distinct colouration of the carapace as illustrated in Fig. 37. The copulatory organ of the male has only one appendage.

\section{Paradoxostoma worooa sp. n.}

(Figs 39-42)

Material

Hol o ty pe: female, March 19, 1988, Lizard Island, Sta. 6; AMS.

Par a ty pe s: Lizard Island: 5 females, May 18, 1988, Sta. 11; 5 females, 2 larvae, August 16, 1989, Sta. 11; 2 females, April 27, 1988, Sta. 13; 1 female, August 8, 1989, Sta. 13; 6 females, May 16, 1988, Sta. 20; 8 females, 4 larvae, August 11, 1989, Sta. 20; 4 females, May 10, 1988, Sta. 21; 6 females, 1 larva, August 15, 1989, Sta. 23; AMS. 2 females, May 17, 1988, Sta. 25; 4 females, August 17, 1989, Sta. 29; ZMH K-34568. Cod Hole: 8 females, August 7, 1989, Sta. 34; ZMH K-34568.

Locus ty picus: Lizard Island, dead coral fragments covered with algae.

Name: "worooa" is the aboriginal word for green and refers to the colour of the carapace.

Description: The carapace is twice as long as high. The dorsal margin is strongly convex and has its maximum height behind the mid region. Anterior and posterior margin are rounded. The ventral margin is slightly concave. The entire carapace is a dark green colour. In the anterior region, there is a large vestibule. In the mouth region, the inner margin and the line of concrescence nearly coincide. The vestibule in the posterior region is not as broad as in the anterior region. The number of marginal pore canals is about 17 . A distinct selvage can be recognized.

The Au has 6 segments and weak bristles. The Aa has 5 segments. The bristle on segment 2 is short and covered with hair. There is only one terminal claw. The $\mathrm{Md}$ is developed as a stinging organ. The Mxu is without special features. Walking legs: P1 has one bristle at its anterior margin. The kneebristle is strong and as long as the following segment. The bristle ventrally on segment 2 is small. The kneebristles of P2 and P3 are weak, the bristles on segment 2 are also weak.

Size : females, LV: length $0.39 \mathrm{~mm}$, height $0.19 \mathrm{~mm}$. 
Re marks: Although $P$. worooa is common around Lizard Island, and specimens were collected during different seasons, males were not found. $P$. worooa differs from other species in its large height compared to its length, its small size and its dark green colour.

$$
\text { Paradoxostoma angulatum sp. n. }
$$

(Figs 45-48)

\section{Material}

Hol ot y pe: male, August 15, 1989, Lizard Island, Sta. 23; AMS.

Par a t y p e s: Lizard Island: 9 females, 19 males, August 23, 1989, Sta. 6; AMS. 2 females, 1 male, August 16, 1989, Sta. 11; 4 females, August 16, 1989, Sta. 12; 1 male, August 5, 1989, Sta. 14; 2 males, August 14, 1989, Sta. 21; ZMH K-34569.

Locus : typicus : Lizard Island, algae.

Na m e: The latin word "angulatus" refers to the angular shape of the carapace.

Description: The dorsal margin of the carapace is convex and has its maximum height just behind the mid region. The posterior margin ends in a tip. There is an angulation at the point where the posterior margin joints the ventral margin. The ventral margin is slightly concave. The anterior margin ends in a tip as well, but is more rounded than the posterior one. In the anterior and posterior parts, vestibules are developed. In the ventral region, the inner margin and the line of concrescence nearly coincide. The number of marginal pore canals is about 14 . The carapace of the female is smaller than that of the male.

The Au has 6 segments with weak bristles. The Aa has 5 segments. The segments 2 , 3 and 4 distoventrally bear one bristle each. The terminal segment has one claw and one bristle. The spinneret bristle has 3 segments and does not reach the terminal claw in length. The Md is developed as a stinging organ. The Mxu is without special features. Walking legs: P1 has a strong kneebristle which is not as long as the following segment. The bristle at the anterior margin of segment 1 is weak, the one at segment 2 is strong. P2 has also a strong kneebristle which is about half the length of the following segment. The bristle on segment 2 is weak. P3 has a weak kneebristle and a weak bristle on segment 2 .

$\mathrm{Siz}$ e: females, LV: length $0.39 \mathrm{~mm}$, height $0.23 \mathrm{~mm}$; males, LV: length $0.41 \mathrm{~mm}$, height $0.24 \mathrm{~mm}$.

R e m a rks: $P$. angulatum mostly occurred on algae. Single specimens were found on dead coral fragments. The species seems to appear seasonally as it was collected only during winter months (September-October), but not in summer (February - April). There is no other species that resembles $P$. angulatum in the shape of the carapace. Anterior and posterior margins are pointed, with a slightly concave ventral margin and an angulation where the ventral margin joints the posterior margin.

Paradoxostoma minya sp. n.

(Figs 49-50)

\section{Material}

Hol o ty pe: male, August 14, 1989, Lizard Island, Sta. 21; AMS.

P a r a ty pes: Lizard Island: 1 female, March 15, 1988, Sta. $5 ; 3$ females, 5 males, August 23, 1989, Sta. 6; 1 larva, August 16, 1989, Sta. 11; 4 females, 2 males, August 16 , 
1989, Sta. 12; 1 larva, April 27, 1988, Sta. 13; 1 female, August 8, 1989, Sta. 13; 1 female, May 3, 1988, Sta. 14; 1 female, August 5, 1989, Sta. 14; AMS. 2 females, 1 male, August 12, 1989, Sta. 25; 1 female, 1 male, 1 larva, August 17, 1989, Sta. 29; ZMH K-34570. Cod Hole: 1 female, August 7, 1989, Sta. 34; ZMH K-34570.

L ocus ty pic us : Lizard Island, algae.

$\mathrm{Na}$ me: The aboriginal word "minya" means small.

Description: The highest point of the dorsal margin of the carapace is near the posterior margin. The dorsal margin forms a distinct angle with the posterior margin which is almost vertical. The ventral margin is slightly concave. The anterior margin is rounded. The fused zone is very broad, especially in the posterior region of the carapace where there are also a lot of false marginal pore canals. A large vestibule is present in the anterior region. The number of marginal pore canals is about 13. The carapace is of golden-brown colour and the eyes of the animal are very distinct.

The Au has 6 segments with weak bristles. The Aa has 5 segments. Ventrodistally there is one bristle on each of the segments 2,3 and 4 . The terminal segment bears only one claw. The spinneret bristle has 3 segments and does not reach the end of the terminal claw. The Md is developed as a stinging organ. The inner endite of the Mxu bears only one bristle. Walking legs: P1 has one bristle at the anterior margin of segment 1 . The kneebristle is coarse, but is only half the length of the following segment. The bristle on segment 2 is strong. P2 and P3 both have one weak kneebristle each. The bristle at the anterior margin of segment 2 is strong on P2 and weak on P3.

$\mathrm{Size}$ : females, LV: length $0.44 \mathrm{~mm}$, height $0.22 \mathrm{~mm}$; males, LV: length $0.40 \mathrm{~mm}$, height $0.20 \mathrm{~mm}$.

Re marks: The carapace of $P$. minya largely resembles $P$. latimarginatum Hartmann, 1979, but is smaller. Both species also differ in the antenna. P. latimarginatum has a bristle besides the terminal claw that $P$. minya lacks. The inner endite of the maxillula bears one bristle in $P$. minya but two bristles in $P$. latimarginatum.

\section{Paradoxostoma sp. Lizard 1}

(Fig. 51)

Material: 3 females, August 16, 1989, Lizard Island, Sta. 12; AMS.

Size: females, LV: length $0.78 \mathrm{~mm}$, height $0.30 \mathrm{~mm}$.

Paradoxostoma sp. Lizard 2

(Fig. 52)

Material: 1 female, August 23, 1989, Lizard Island, Sta. 6; 1 female, August 17, 1989, Sta. 29; AMS.

Siz e: females, LV: length $0.53 \mathrm{~mm}$, height $0.25 \mathrm{~mm}$.

Acknowledgements. I would like to thank Prof. Dr G. Hartmann for proposing the subject of this investigation and for his encouragement during the progress of the study. Thanks are also due to J. K. Kirch and O. Gross for assistance in collecting the material, also to J. Elliott and S. Meyer for correcting the English of the manuscript. These studies were supported by the Amalie Dietrich Fellowship 1988 of the Australian Museum, Sydney, and the article is based on a doctoral study in the Faculty of Biology, University of Hamburg. 


\section{LITERATURE CITED}

Behrens, P., 1991. Ostracoda (Crustacea) from Lizard Island, northern Great Barrier Reef, Australia. I. Families: Cytherellidae, Loxoconchidae, Cytherideidae, Cytheruridae, Paracytherideidae, Pectocytheridae, Krithidae, Cytheromatiidae, Bythocytheridae, Cytheridae. - Helgoländer Meeresunters. $45,107-142$.

Bonaduce, G., Masoli, M., Minichelli, G. \& Pugliese, N., 1980. Some new benthic marine ostracod species from the Gulf of Aqaba (Red Sea). - Boll. Soc. paleont. ital. 19, 143-178.

Hartmann, G., 1978. Die Ostracoden der Ordnung Podocopida G. W. Müller, 1894 der tropischsubtropischen Westküste Australiens (zwischen Derby im Norden und Perth im Süden). - Mitt. hamb. zool. Mus. Inst. 75, 63-219.

Hartmann, G., 1979. Die Ostracoden der Ordnung Podocopida G. W. Müller, 1894 der warmtemperierten (antiborealen) West- und Südwestküste Australiens (zwischen Perth im Norden und Eucla im Süden.) - Mitt. hamb. zool. Mus. Inst. 76, 219-301.

Hartmann, G., 1981. Die Ostracoden der Ordnung Podocopida G. W. Müller, 1894 der subtropischtropischen Ostküste Australiens (zwischen Eden im Süden und Heron Island im Norden). - Mitt. hamb. zool. Mus. Inst. 78, 97-149.

Hartmann, G., 1984. Zur Kenntnis der Ostracoden der polynesischen Inseln Huahiné (Gesellschaftsinseln) und Rangiroa (Tuamotu-Inseln). - Mitt. hamb. zool. Mus. Inst. 81, 117-169.

Reed, A. W., 1965. Aboriginal words of Australia. Reed Books, Terrey Hills, 144 pp. 

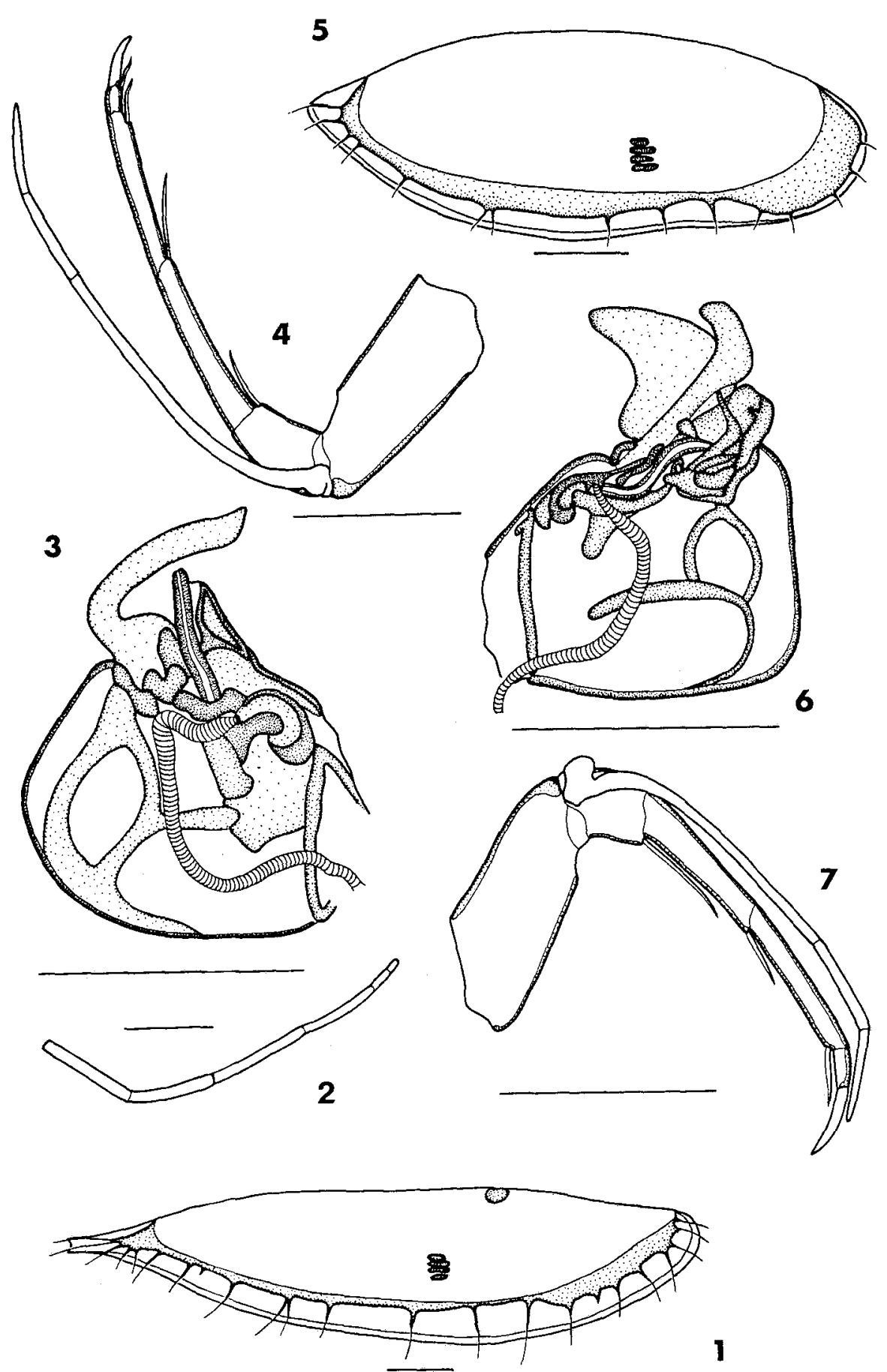

Figs 1-4. Paradoxostoma cf. navicula Bonaduce; Masoli, Minichelli \& Pugliese; 1980. 1: Fernale LV from inside $($ Scale $=0.1 \mathrm{~mm}) .2:$ Au: 3: Male copulatory organ. 4: Aa (Scales of Figs 2-4= $0.05 \mathrm{~mm}$ )

Figs 5-7. Paradoxostoma lizardensis sp. n. 5: Female LV from inside (Scale $=0.1 \mathrm{~mm}$ ). 6: Male copulatory organ. 7: Aa (Scales of Figs $6-7=0.05 \mathrm{~mm}$ ) 


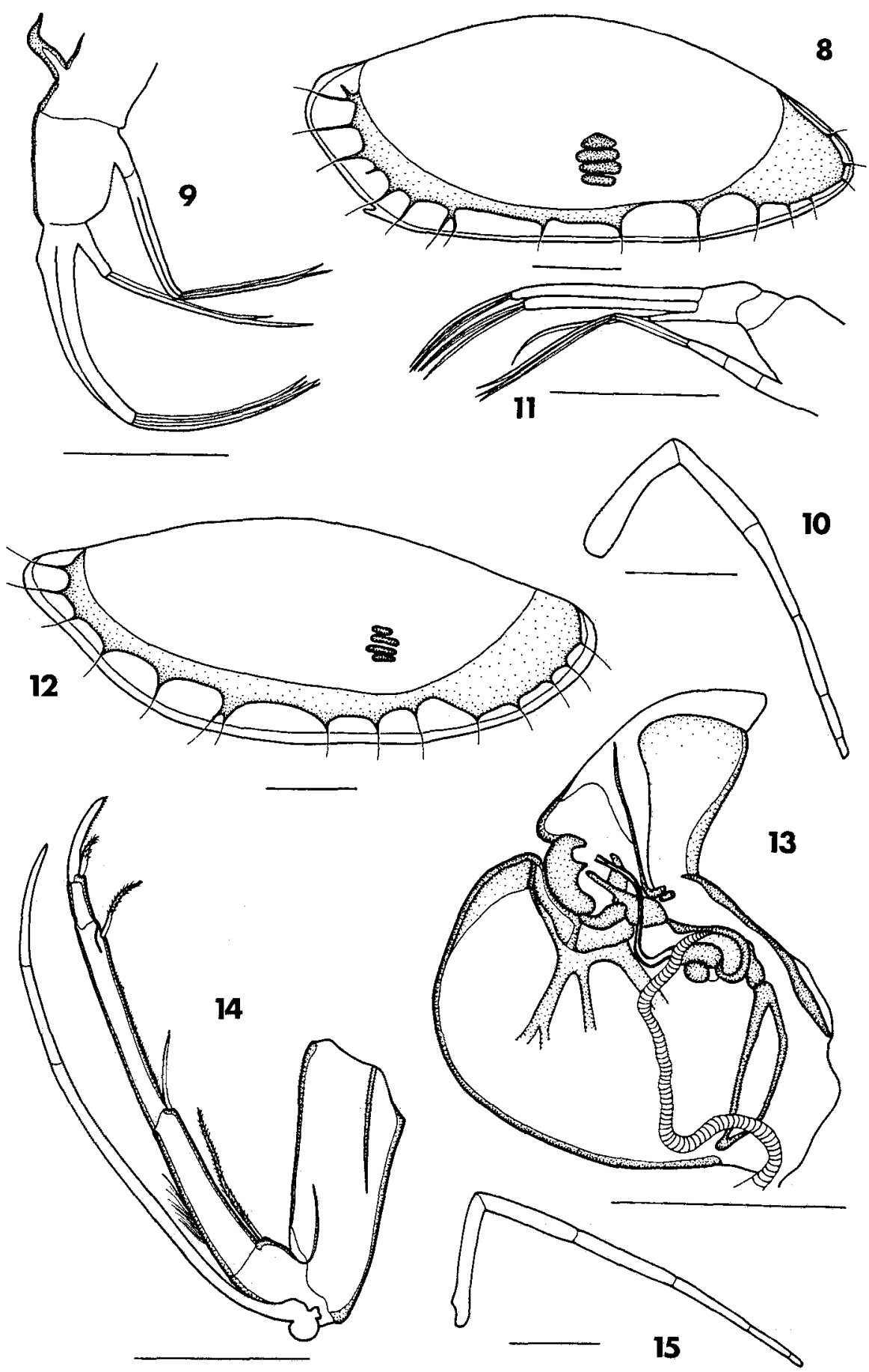

Figs 8-10. Paradoxostoma aculeatum. sp. n. 8: Male LV from inside (Scale $=0.1 \mathrm{~mm}$ ). 9: Mxu. 10: Au (Scales of Figs 9-10 $=0.05 \mathrm{~mm}$ )

Figs 11-15. Paradoxostoma melania sp.n. 11: Mxu (Scale $=0.05 \mathrm{~mm}$ ). 12: Male LV from inside $($ Scale $=0.1 \mathrm{~mm})$. 13: Male copulatory organ. 14: Aa. 15: Au (Scales of Figs 13-15=0.05 mm) 


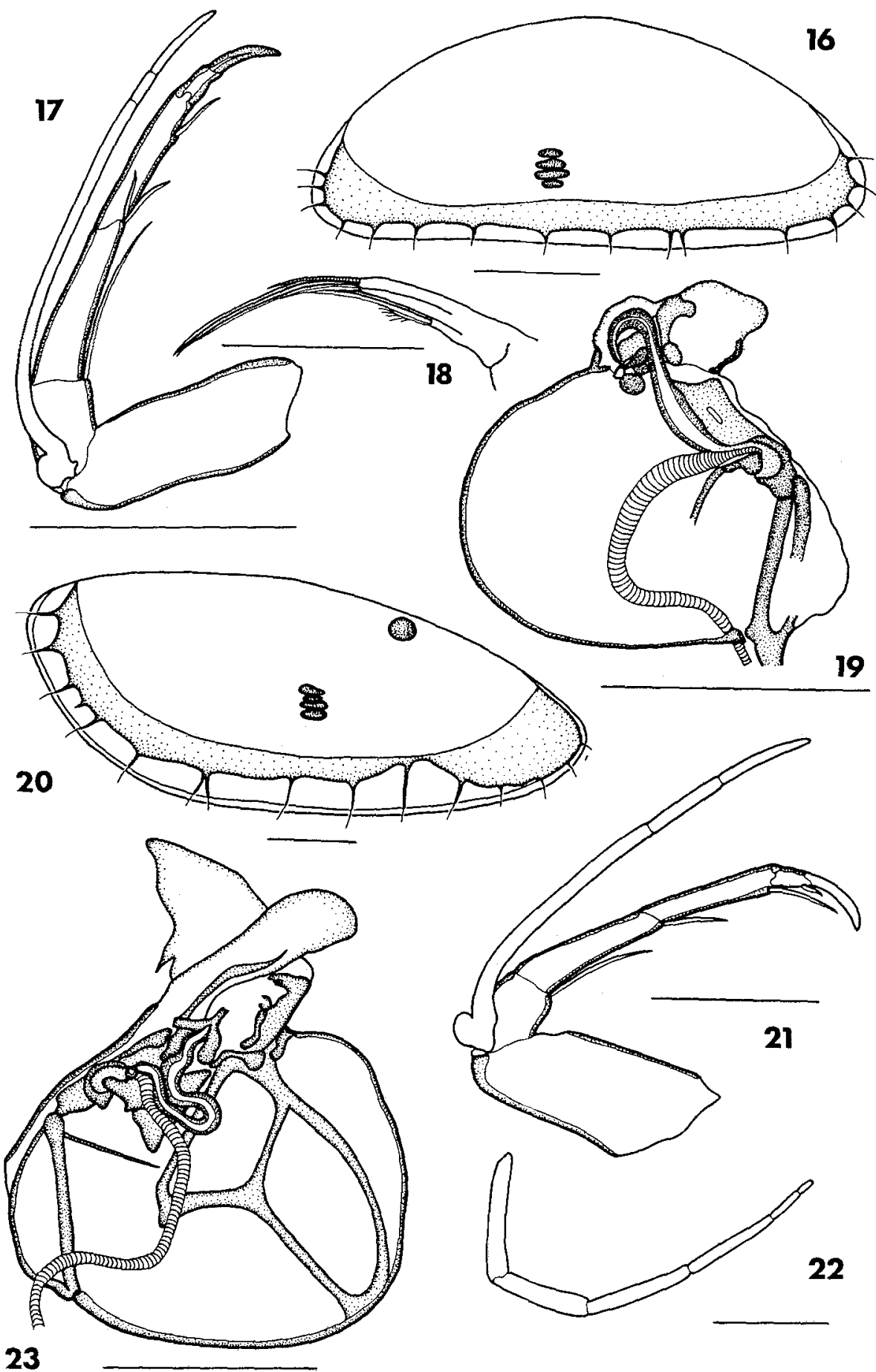

Figs 16-19. Paradoxostoma moonga sp. n. 16: Female RV from inside (Scale $=0.1 \mathrm{~mm}$ ). 17: Aa. 18: Mxu. 19: Male copulatory organ (Scales of Figs $17-19=0.05 \mathrm{~mm}$ )

Figs 20-23. Paradoxostoma tiwiwarrin sp. n. 20: Male LV from inside (Scale $=0.1 \mathrm{~mm}$ ). 21: Aa. 22: Au. 23: Male copulatory organ (Scales of Figs $21-23=0.05 \mathrm{~mm}$ ) 

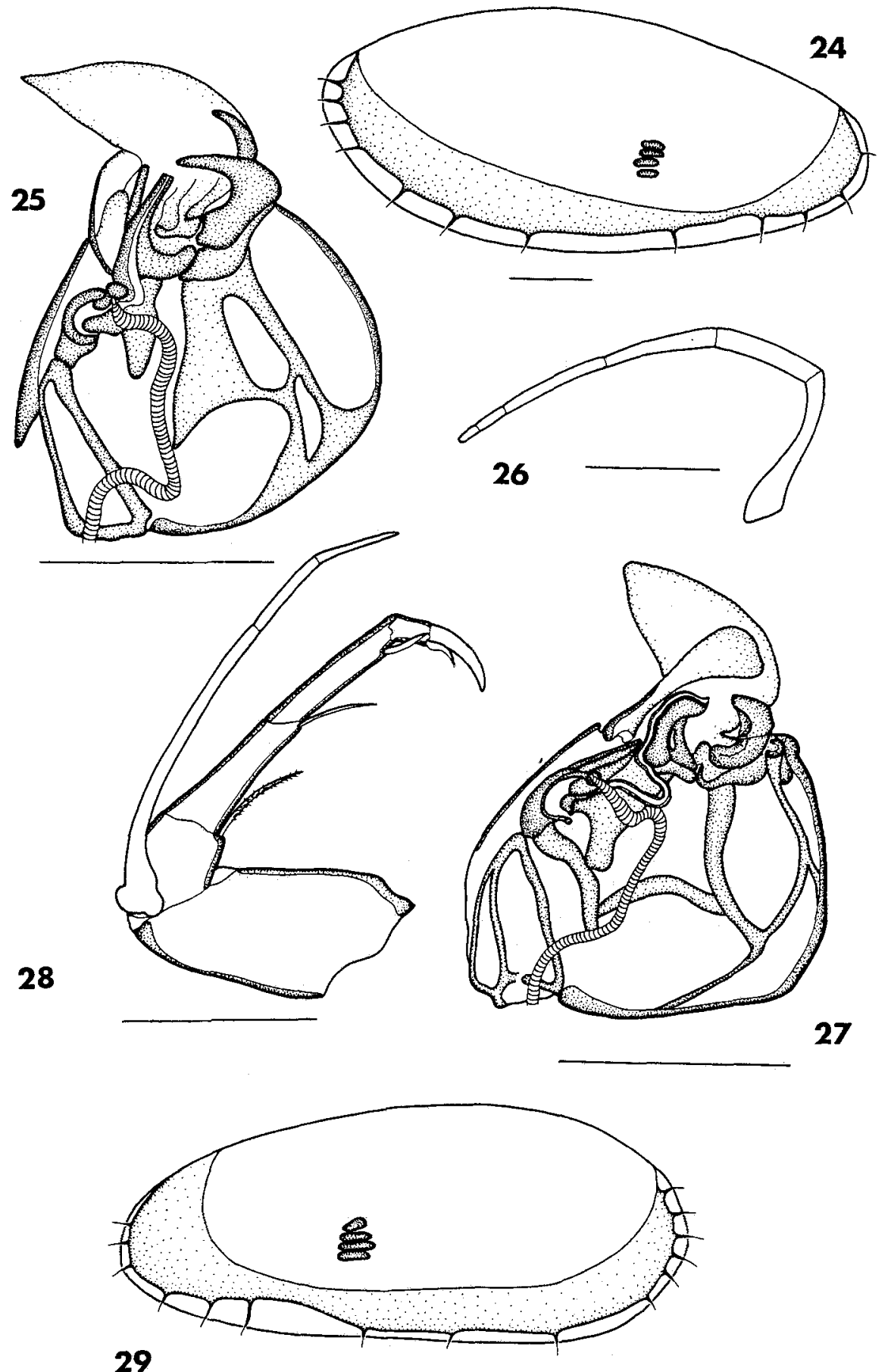

29

Figs 24-26. Paradoxostoma virgatum sp. n. 24: Female LV from inside (Scale =0.1 mm). 25: Male copulatory organ. 26: Au (Scales of Figs 25-26=0.05 mm)

Figs 27-29. Paradoxostoma congruens sp. n. 27: Male copulatory organ. 28: Aa (Scales of Figs $27-28=0.05 \mathrm{~mm}$ ). 29: Female RV from inside (Scale $=0.1 \mathrm{~mm}$ ) 

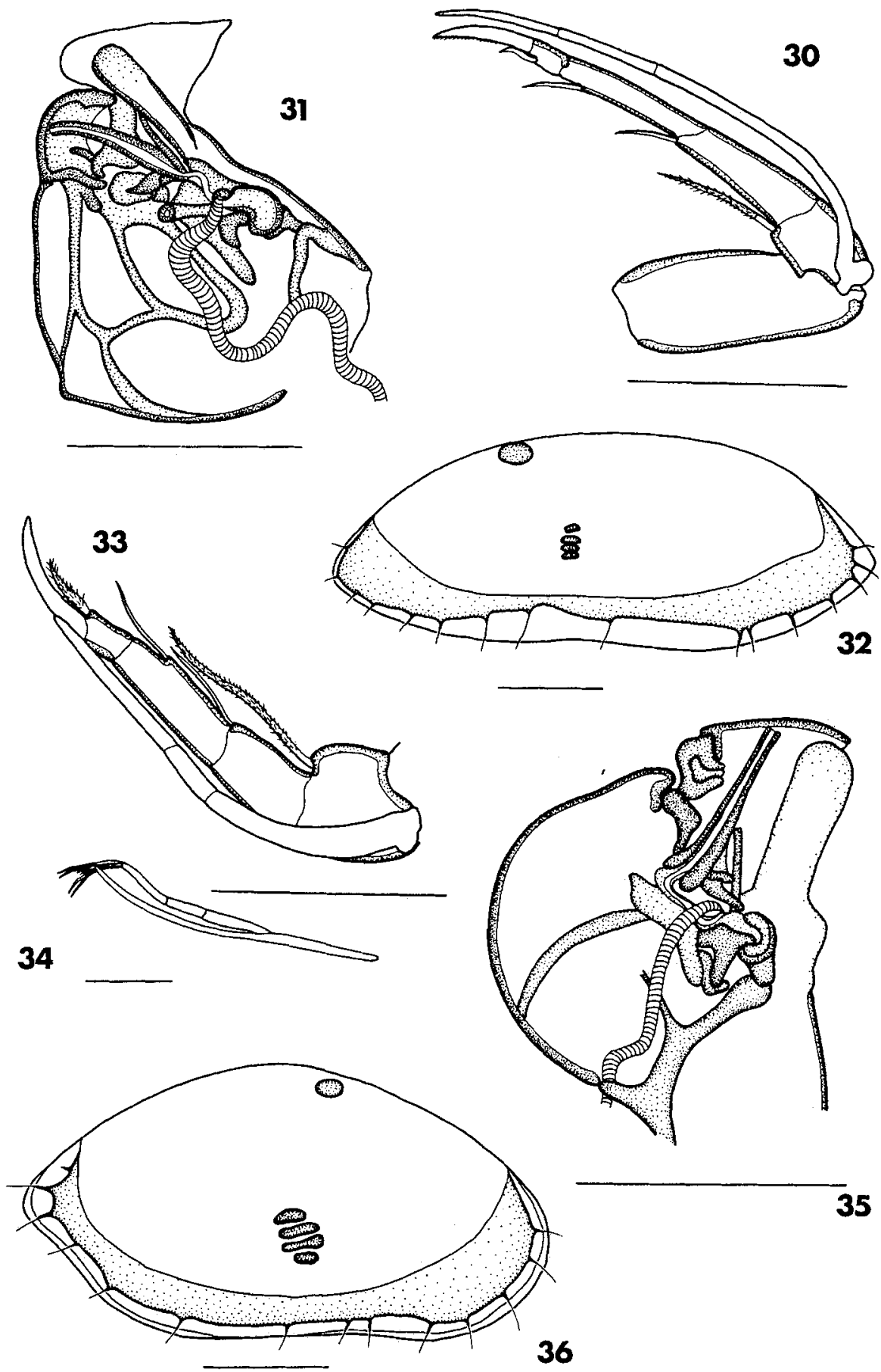

Figs 30-32. Paradoxostoma waminoa sp. n. 30: Aa. 31: Male copulatory organ (Scales of Figs 30-31 $=0.05 \mathrm{~mm}$ ). 32: Male RV from inside (Scale $=0.1 \mathrm{~mm}$ )

Figs 33-36. Paradoxostoma maldum sp. n. 33: Aa. 34: Md. 35: Male copulatory organ (Scales of Figs $33-35=0.05 \mathrm{~mm}$ ). 36: Male LV from inside (Scale $=0.1 \mathrm{~mm}$ ) 

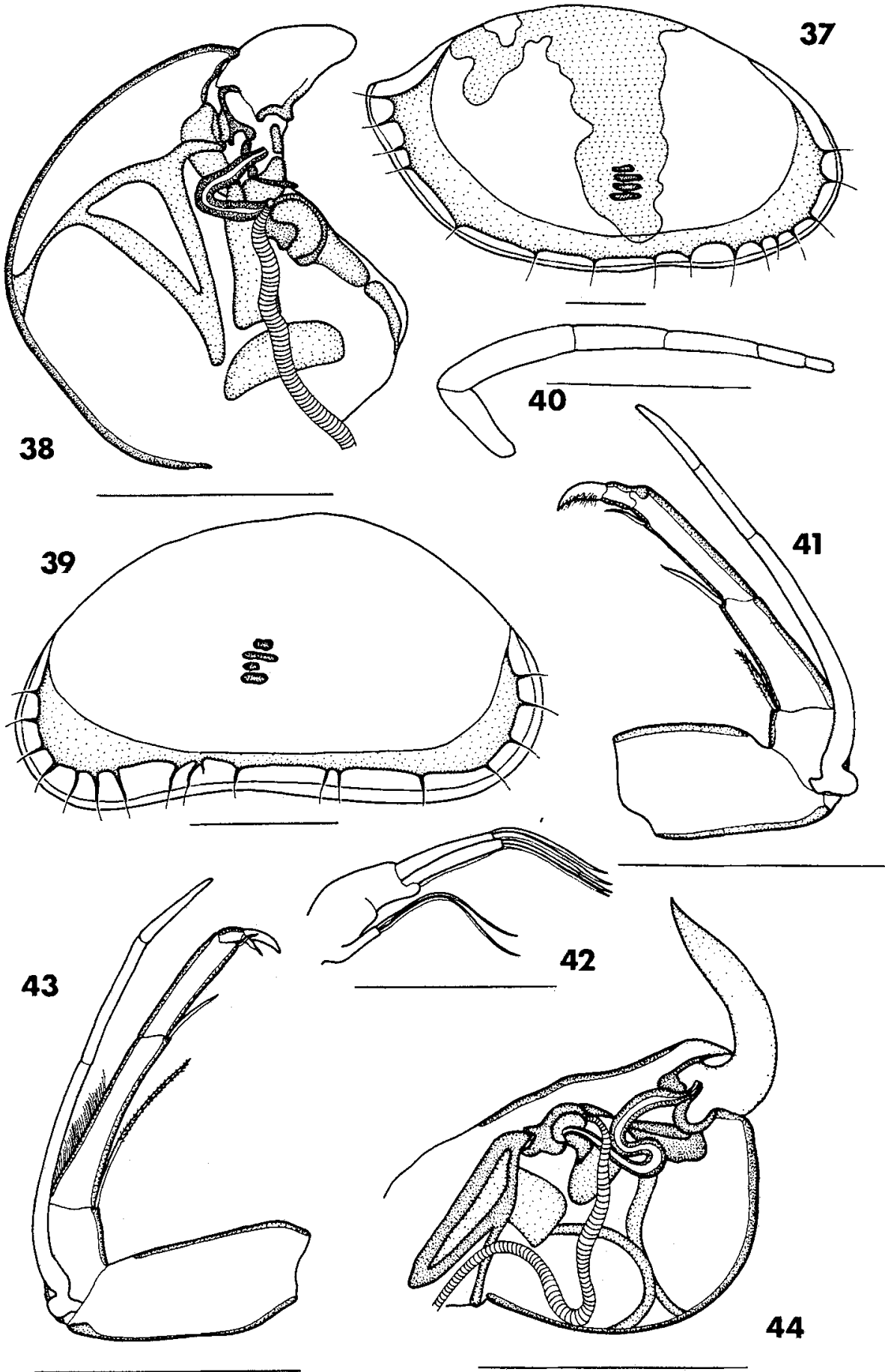

Figs 37-38. Paradoxostoma kurrawa sp. n. 37: Female LV from inside (Scale $=0.1 \mathrm{~mm}$ ). 38: Male copulatory organ (Scale $=0.05 \mathrm{~mm}$ )

Figs 39-42. Paradoxostoma worooa sp. n. 39: Female RV from inside (Scale $=0.1 \mathrm{~mm}$ ). 40: Au. 41: Aa. 42: Mxu (Scales of Figs 40-42=0.05 mm)

Figs 43 44. Paradoxostoma aculeatum sp. n. 43: Aa. 44: Male copulatory organ (Scales of Figs $43-44=0.05 \mathrm{~mm}$ ) 


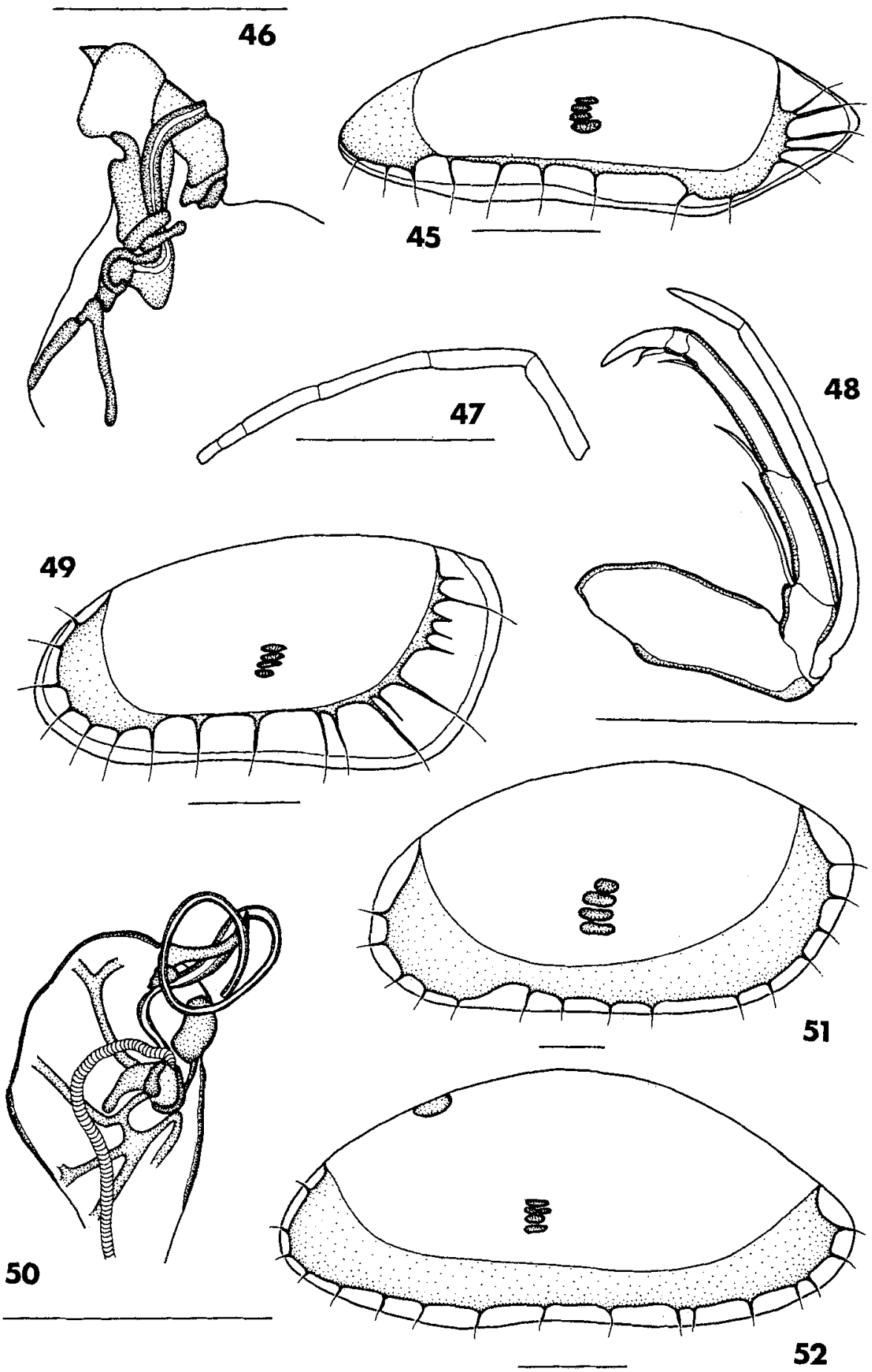

Figs 45-48. Paradoxostoma angulatum sp. n. 45: Male RV from inside (Scale $=0.1 \mathrm{~mm}$ ). 46: Male copulatory organ. 47: Au. 48: Aa (Scales of Figs $46-48=0.05 \mathrm{~mm}$ )

Figs 49-50. Paradoxostoma minya sp. n. 49: Female RV from inside (Scale $=0.1 \mathrm{~mm}$ ). 50: Male copulatory organ (Scale $=0.05 \mathrm{~mm}$ )

Fig. 51. Paradoxostoma sp. Lizard 1. Female RV from inside (Scale $=0.1 \mathrm{~mm}$ )

Fig. 52. Paradoxostoma sp. Lizard 2. Female RV from inside (Scale $=0.1 \mathrm{~mm}$ ) 